DOI: $10.20472 / E F C .2017 .007 .014$

\title{
IGNAS MIKALAUSKAS
}

Vilnius University, Lithuania

\section{THE COSTS OF INNOVATIVE RENEWABLE ENERGY SOURCES IN MODERN SOCIETY}

\begin{abstract}
:
The importance of technological advances reaches each and every one. New innovations drive the world we live in, form societies and economies around us. One of the main and primitive questions to every day human is whether or not he can afford a new technology, for a manufacturer - can he make a profit of selling it, for an environmentalist - how will it impact the future? One thing is certain - none of that can be answered if it's unknown whether the technology is reachable to every day user, starting from the price of the technology itself, including different levels of investments, ending with the costs of actually installing the technologies to common households worldwide, for green, economically growing and sustainable future.
\end{abstract}

\section{Keywords:}

renewable energy, innovative renewable energy sources, cost of energy 


\section{Introduction}

People all over the world are counting on technologies. It is important to understand that partly the existence of humanity itself relies on future technological innovations and our capabilities of managing to apply them to our benefit. Currently one of the biggest challenges is mitigating climate change. One of the solutions is the introduction of RES (renewable energy sources). The potential of renewable energy sources is enormous as they can in principle meet many times the world's energy demand (Herzog, Lipman, Kammen, 2001, p. 8).

New, innovative renewable energy technologies are sorted into 5 different groups: solar, wind, water, bio and others (Ferry, Monoian, 2012). Looking at the latest trends and how the industry has adopted the uprising of renewable energy, according to a report by REN21 (2016):

- water (or hydro) power in 2015 has reached a growth rate of $2.9 \%$ by end-2010 through 2015;

- wind power reached $17 \%$ growth rate by end-2010 through 2015;

- solar (Photovoltaic or PV) reached 42\% growth rate by end-2010 through 2015;

The large increase of solar energy sources has been projected before due to the fact that there is a limit on current energy systems, such as hydropower plants, where you can't dam the same river close by twice without causing major environmental catastrophes (Rosenberg, McCully, Pringle, 2000, p. 749). New types of research of creating small dams and producing electricity from redirecting water come at high uncertainty and are still at the idea stage (Ferry, Monoian, 2012, p. 34).

Wind power systems come at high-cost barrier and required space, which at this point is not integrated into the society without causing societal and environmental problems, as well as the sound reduction of the working power plant (Hansen, 2015, p. 3). Different types of wind power plants have different side effects.

New and innovative completely emission free bioenergy sources are still a way to go due to its complexity in understanding, creating and manufacturing. All this causes tremendous logistical problems that will be (if certain efficiency over others is met) faced in the future (Faaij, 2006, p. 340).

To find out what is the most efficient way of producing electricity from renewable energy sources is to measure what is the cost of it in money (in our case - $€$ ) by how much electricity it produces (in our case - kilowatt or megawatt hours). It must be noted that the cheapest electricity production doesn't necessarily mean the best option. There are others factors to be accounted for, such as environmental and social effects from generating power, where environmental effects play a crucial role and cannot be forgotten. 


\section{Determining the cost of energy}

One of the ways to determine what the cost of energy is by calculating LCOE (levelized cost of energy). LCOE measures lifetime costs divided by energy production, calculates the present value of the total cost of building and operating a power plant over an assumed lifetime, allows the comparison of different technologies (e.g., wind, solar, etc.) of unequal lifespans, project size, different capital cost, risk, return and capacities (Levelized cost of energy, 2015). LCOE is the price (per kWh) for generated electricity that makes the net present value of the installation zero. If the sales price if lower than the LCOE, the project will not provide the required return thus it is a measure of the cost of ownership of the power generating system (Green Rhino Energy, 2016).

The most basic and explaining formula (1) for calculating levelized cost of energy:

$$
L C O E=\frac{\text { lifetime costs }}{\text { lifetime energy }}=\frac{\sum_{t=1}^{N}\left[\frac{I_{t}+O M_{t}+F_{t}-I P_{t}}{(1+r)^{t}}\right]}{\sum_{t=1}^{N}\left[\frac{E_{t}}{(1+r)^{t}}\right]}
$$

$I_{t}$ - investment cost in year $\mathrm{t}$;

$O M_{t}$ - operations and maintenance costs in year t;

$F_{t}$ - fuel costs in year $\mathrm{t}$;

$I P_{t}-$ investment and production tax credits in year $\mathrm{t}$;

$E_{t}$ - generated energy in year t;

$r$ - discount rate or WACC (weighted average cost of capital);

$N-$ a total lifetime of the project in years.

Another important variable in determining the cost of energy is capacity factor. The net capacity factor of a power plant is the ratio of the net electricity generated, for the time considered, to the energy that could have been generated at continuous full-power operation during the same period (U.S. Nuclear Regulatory Commission, 2016). CSP (concentrated solar power) capacity factor in California is 33\% (Ivanpah solar electric generating station, 2012) and in Spain - 63\% (Torresol energy gemasolar thermosolar plant, 2014). This shows that different systems can have and will have different parameters depending on many factors that lay in the economy, geographic standings, etc. By calculating LCOE for renewable energy sources it is also possible to determine the amount of $\mathrm{CO}_{2}$ and other GHG (greenhouse gas) emissions that are being saved if we are replacing current nonrenewable energy systems with new renewable energy systems.

\subsection{Used renewable energy practice}

To better understand and visualize what levelized costs for renewable energy sources are, analysis by 4 different agencies is provided with a year span from 2014 to 2016 to 
see the most recent calculations that have been done. Measurements for visual presentation is set to $\$$ USD per MWh of electricity produced. Due to capital costs, discount rate, currency disbalance, etc., it is correct to present the numbers in the original measurements that were made originally in the reports accordingly.

Figure 1: International LCOE by range by IRENA, 2015

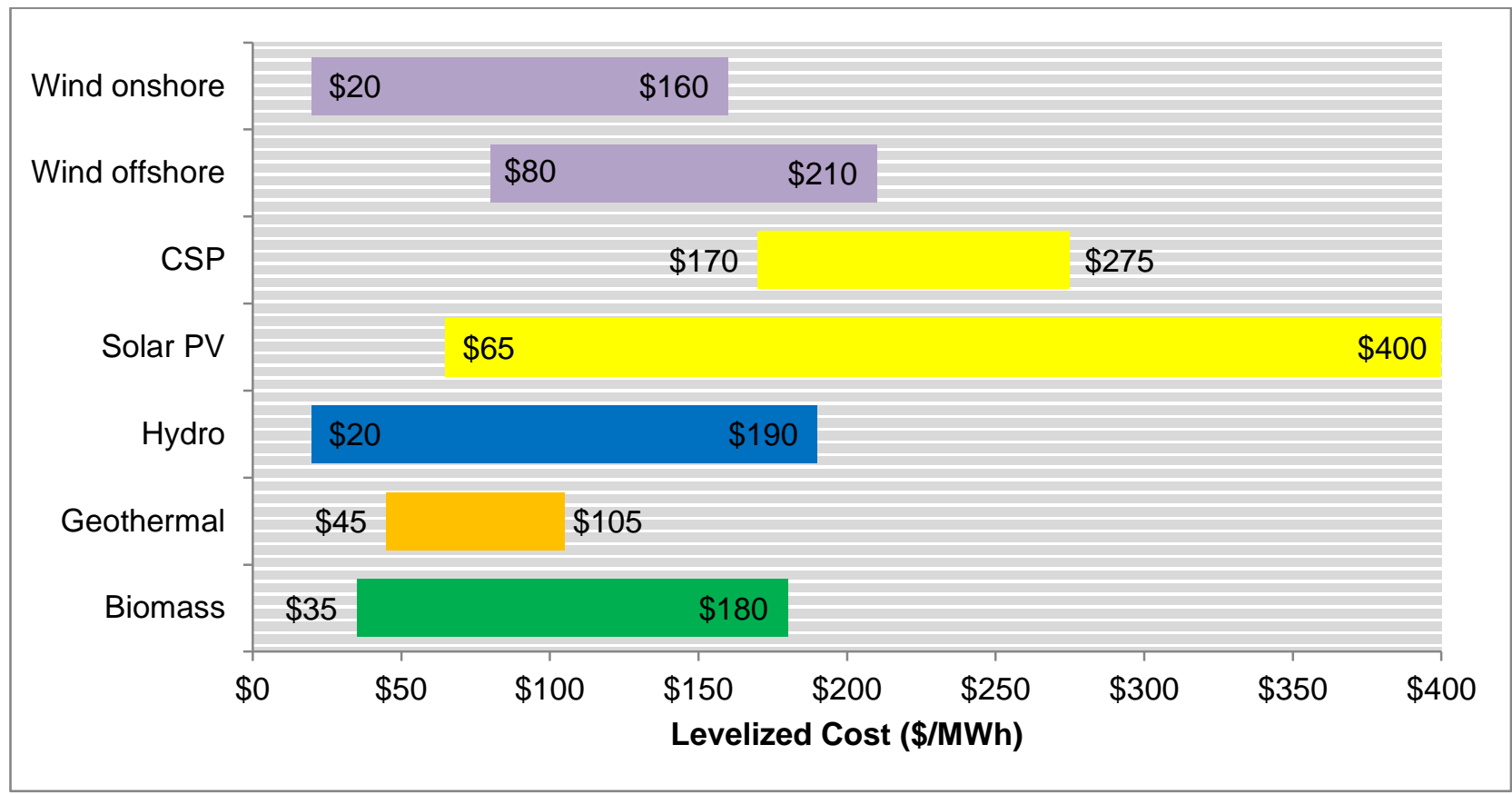

Source: created by author based on IRENA (2015).

IRENA study in 2014 shows low costs for onshore wind, hydro, geothermal and biomass power plants. Lowest range varies for geothermal and CSP power plants. This study has been made throughout a variety of countries thus it means that you can acquire very cheap parts in China where the LCOE will be lower in consideration with nonmanufacturers European countries. This explains why there is such a big LCOE range for all of the power plants. The bigger the comparison of countries, the more diversified the results will be.

A study in the US (United States) by LAZARD in 2015 has shown a variety of renewable energy sources. In this case, solar RES were expanded into different sections which give a very good look at how different solar power plants costs can be, depending on the technology used to produce, manufacture and install it. This is a greater and deeper look into actual LCOE for a specified section, although the numbers will be approximate between different US states with different solar capacities. 
Figure 2: U.S. LCOE range by LAZARD, 2015

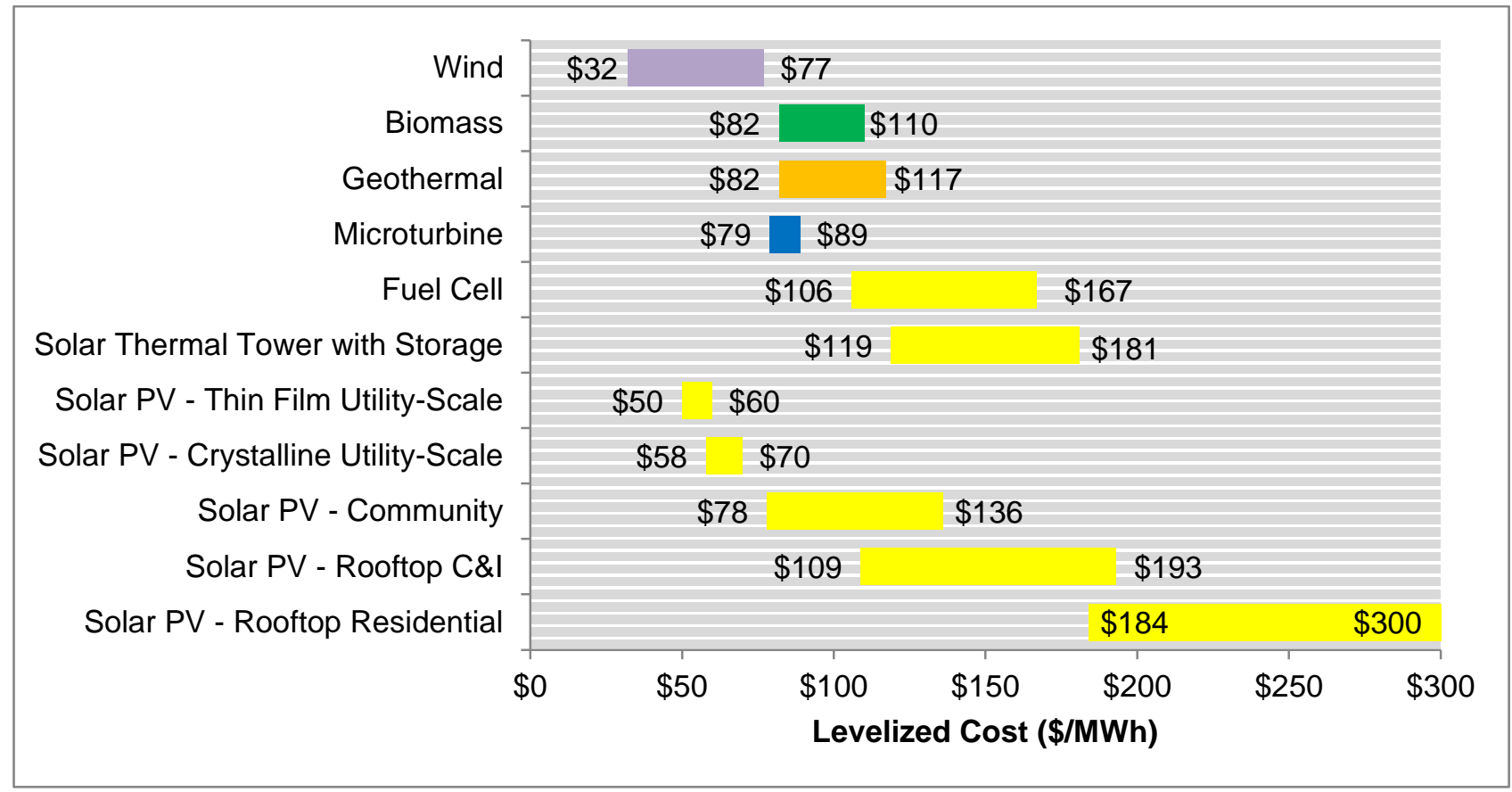

Source: created by author based on LAZARD (2015)

Dominant cheapest RES is the wind energy, followed by solar thin film and crystalline technology. While wind technology still has a certain range of price, new technologies, such as: microturbines, solar thin film and crystalline technologies, scored a very low range of price. This means that this kind of technology is developed in a way that its appliance in different areas will have nearly the same result, bringing a united cost for electricity.

Next study by IEA and NEA in 2015 counted mainly wind and solar technologies and has been studied in the following countries: Austria, Belgium, Brazil, China, Denmark, Finland, France, Germany, Hungary, Italy, Japan, Korea, Netherlands, New Zealand, Portugal, Slovak Republic, South Africa, Spain, Switzerland, Turkey, United States and United Kingdom. This shows a great variety of countries meaning that the range of price is bound to be very high comparing to the previous study, where there was a very low range of price in certain areas, such as solar.

This kind of jumping prices cannot be avoided in larger studies between countries in different continents but it is crucial to also see the similarities between them. These similarities can show a construct of how future development of RES can be done in a work that is deployed internationally with all of its strengths and weaknesses including the social and environmental differences. 
Figure 3: International LCOE by average (median) and range, $7 \%$ discount rate, by IEA and NEA, 2015

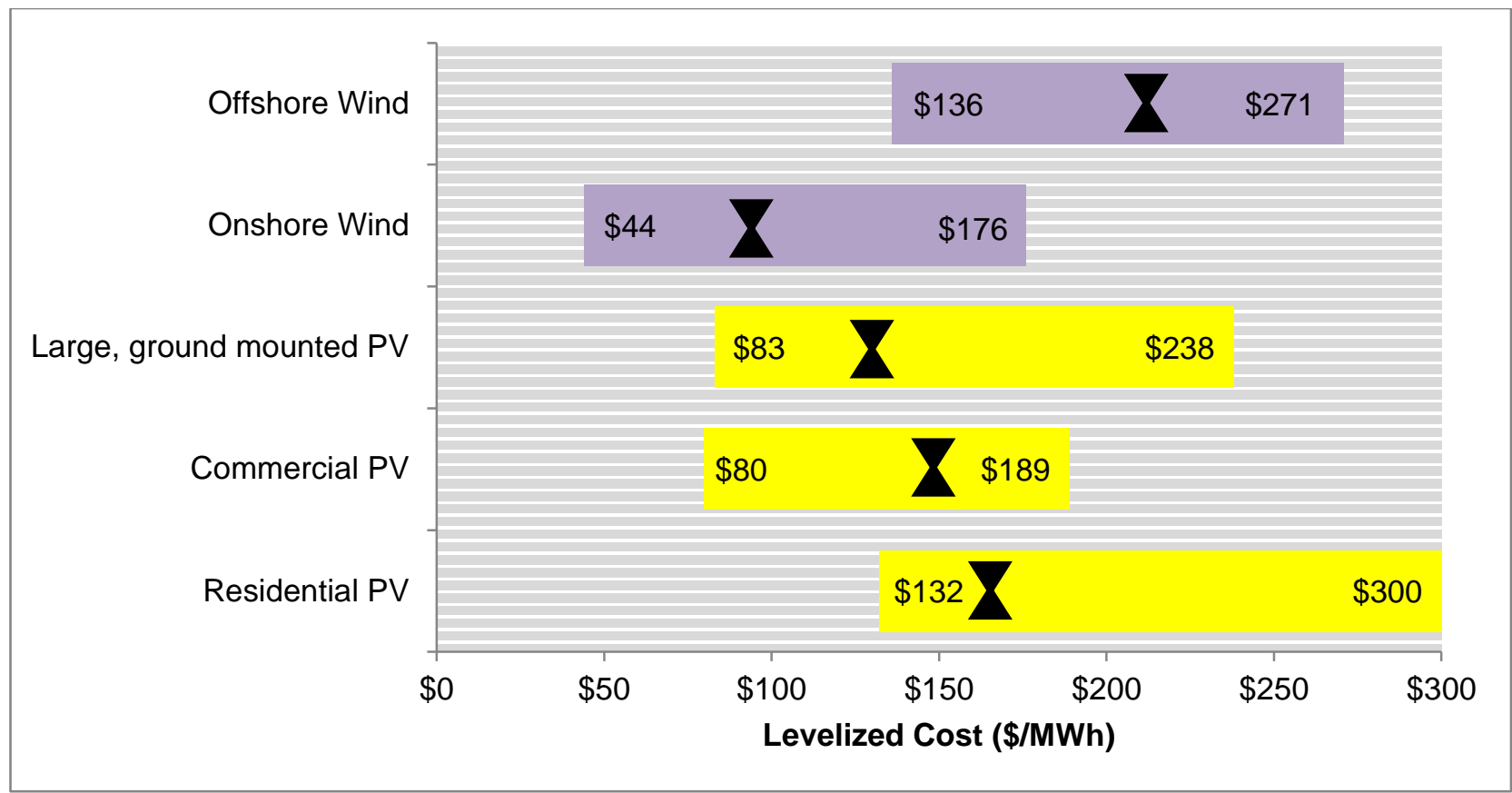

Source: created by author based on IEA, NEA (2015)

Previous two studies did not have an average or median cost, this one was done by IEA and NEA does have. While it only studies 2 types of RES, it still has a very high price range, where solar PV energy sources come from just as low as $80 \$ / \mathrm{MWh}$ and go as high as $238 / 300 \$ / M W h$. Same is with both onshore and offshore wind RES, only this time onshore wind varies between 44 and 176 \$MWh where offshore wind RES varies between 136 and $271 \$ / \mathrm{MWh}$. In this study surprisingly all of the solar PV LCOE are extremely high and it raises questions about how different each study calculation sensitivity is.

A most recent study by GSR in 2016 between wind, solar, hydro, geothermal and bio RES showed most diversified results between all of these energy sources. While having the average LCOE doesn't always mean that the price of RES will be close to that. Some countries in Europe have more sea or ocean wind, some have more sunlight than others, but it also comes down to the government policies, taxes, general infrastructure which determines LCOE, which means that the same project can cost substantially more or less in two different countries which are geographically next to each other. 
Figure 4: Europe LCOE by average (median) and range by REN21, 2016

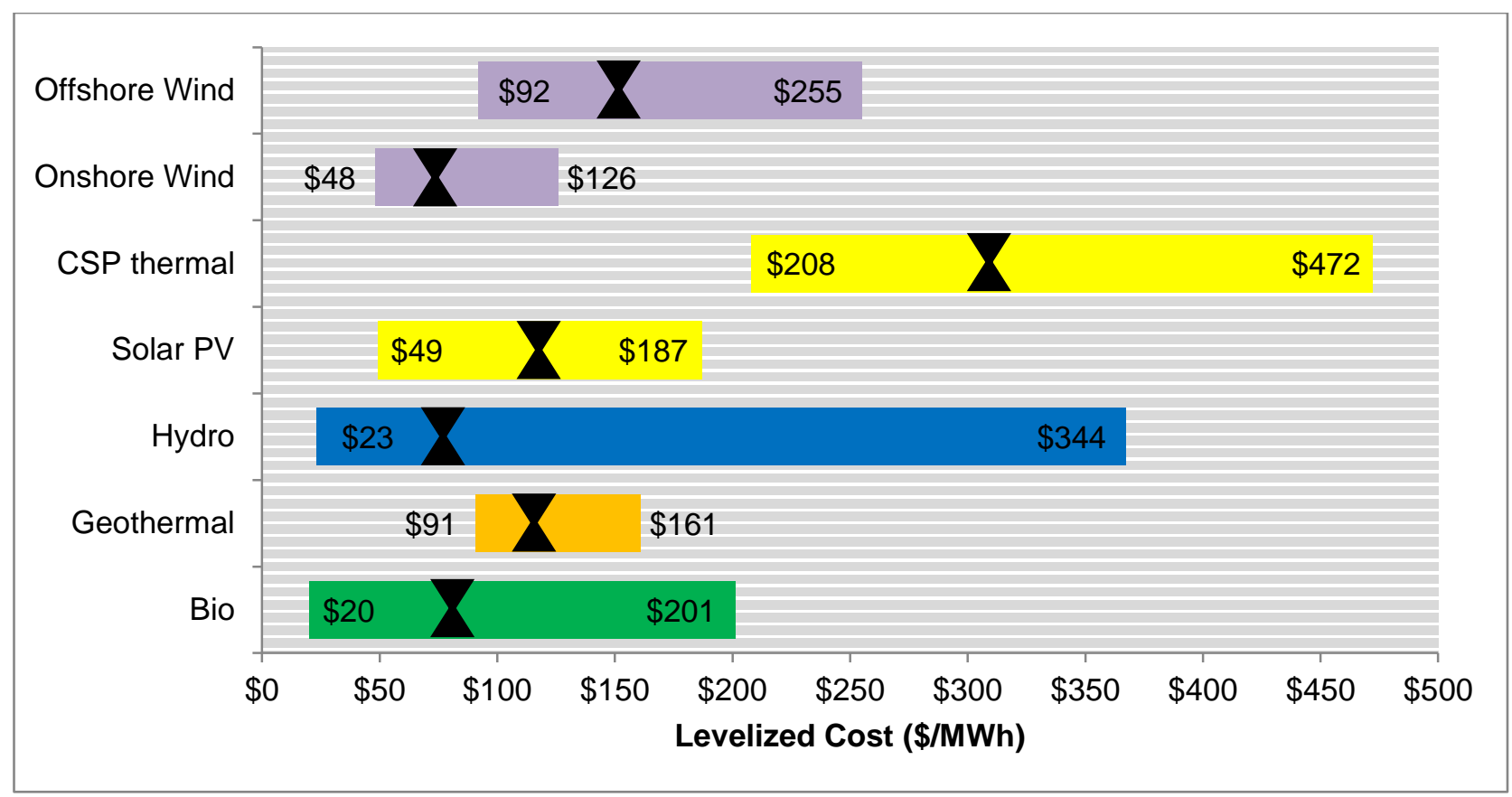

Source: created by author based on REN21 (2016)

In this recent case, all of the RES LCOE were low, compared to current electricity prices in most of the EU countries ${ }^{1}$, except for CSP RES, which went significantly high in prices, reaching up to $472 \$ / M W h$. Onshore wind, hydro and bio power plants had about the same average prices, following by a little more expensive geothermal and solar PV RES.

It is a must to realize that all of the studies made were based on different methodologies which leads us to a gap in one and standardized LCOE calculation methodology. With this kind of instrument, it would be available to calculate little segments of LCOE in different countries to have the smallest price range which would allow for all of the shareholders and other concerned parties, both private and governmental, to have a clear view of what's in front of them in the future technological tendencies.

${ }^{1}$ Average of 0,211 EUR/kWh for EU 28 countries (Eurostat, 2016) 


\subsection{Levelized cost of energy for future renewable energy sources in Lithuania}

It is difficult to set a standard for methods that can be used for future purposes because of the variables that lay ahead. To calculate levelized costs of energy for future scenarios, we must evaluate the current situation as shown in figure 5, which provides with what is the current RES situation in Lithuania ${ }^{1}$.

Figure 5 shows what the amount of different RES throughout the land is; what separate and total capacity at 2016.11.14 is; how much electricity has been generated from these sources during 2015; two different coefficients, showing the relationship between generation and capacity, and capacity and amount.

Figure 5: Energy capacity and generation in Lithuania, 2015 and 2016

\begin{tabular}{|c|c|c|c|c|c|}
\hline RES & Solar & Wind & Blo-mass/gas & Hydro & Total \\
\hline $\begin{array}{l}\text { Amount, n } \\
\text { (2016) }\end{array}$ & 2231 & 150 & $11+39$ & 99 & 2530 \\
\hline $\begin{array}{c}\text { Capacity, MW } \\
\text { (2016) }\end{array}$ & 72,28 & 493,781 & $59,96+34,021$ & 127,909 & 787,951 \\
\hline $\begin{array}{l}\text { Generation, } \\
\text { GWh (2015) }\end{array}$ & 73,3 & 835,76 & 404,5 & 427,2 & 1740,76 \\
\hline $\begin{array}{l}\text { Coefficient, } \\
\qquad \mathbf{k}_{1} ; \mathbf{k}_{2}\end{array}$ & 1,$014 ; 0,033$ & 1,$693 ; 5,572$ & 4,$304 ; 8,090$ & 3,$340 ; 4,315$ & \\
\hline
\end{tabular}

Source: created by author based on LRV (2016)

From figure 5 it is obvious that at the current state, most efficient energy generation is from biomass and biogas, following hydro. Biomass and biogas were more than 4 times as efficient as solar power while having 44 times fewer power plants. The highest amount of electricity generated was from wind power, but it also had highest capacity and potential.

For calculations in Lithuania, estimated discount rate is $5 \%$. No geothermal energy is calculated due to the fact there is no potential geothermal activity. Main capital and other costs for some parts are converted from USD to EUR at 1/0.9387 rate.

Figure 6 displays LCOE in Lithuania, where the advanced RES would be launched between the years 2020-2025.

\footnotetext{
${ }^{1}$ More detailed and visual information, regarding energy capacity and generation in Lithuania, can be found via figure 5 source.
} 
Figure 6: LCOE in Lithuania for advanced RES, estimated start 2020-2025

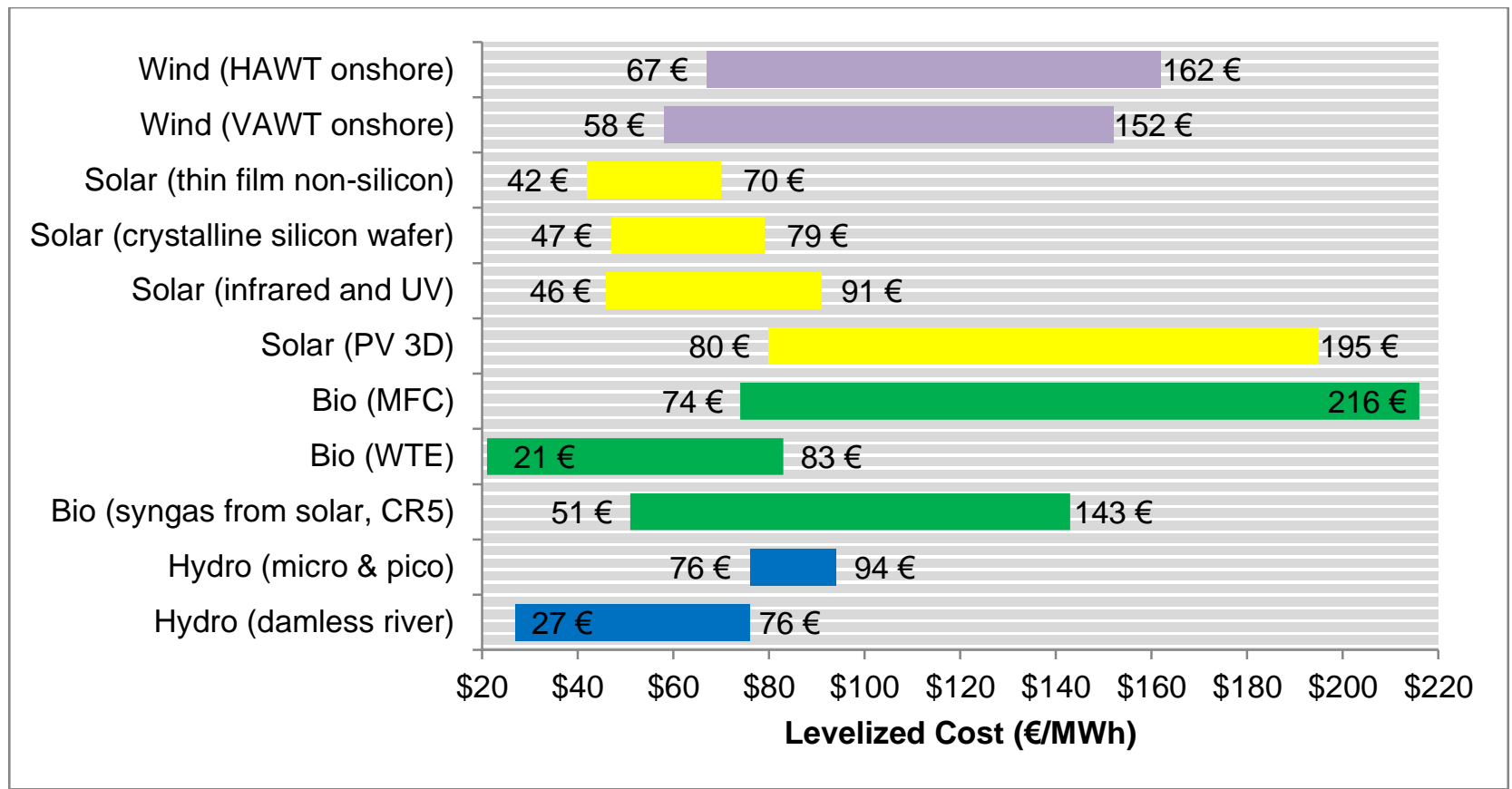

Source: created by author based on own calculations.

Wind. Horizontal axis wind turbine (HAWT) calculated LCOE range from 67 to 162 $€ / M W h$ and vertical axis wind turbine (VAWT) from 58 to $152 € / M W h$. Both of these technologies are similar one to another except the basic structure of the turbine itself. New and improved HAWT designs allow them to capture more energy at high speeds and advanced VAWTs manage to capture the wind at very low wind speed, making them efficient at areas which are further away from the coast and do not have high peak winds.

Solar. Solar energy is becoming more and more available due to the fact that it is cheaper to manufacture and construct solar power plants, experiment with new types and designs. Thin film (made from other semiconductors than silicon, depending on predicted market prices) solar power plants are calculated to produce electricity at $42-70 € / \mathrm{MWh}$, crystalline silicon wafer (substrate) - $47-79 € / \mathrm{MWh}$, conversion of infrared and UV light to electrical power with the condition it will be able to generate electricity 24 hours a day with the current predictions $-46-91 € / M W h$ and 3D PV cells $-80-195 € / M W h$.

Bio. Microbial fuel cells (MFC) can produce electricity by harnessing the natural bioelectrical systems that convert chemical energy into electrical energy in anaerobic microbial ecosystems (Ferry, Monoian, 2012, p. 59) and can cost from 74 to $216 € / M W h$, while waste to energy (WTE) biopower plants (mostly gasification) can do the same at 21 - $83 € / M W h$ and at the same time dispose of non-recyclable waste. Synthesis gas (syngas) with experimental devices such as counter-rotating ring receiver reactor recuperator, depending greatly on the amount of electricity that can be gathered from solar or wind power stations, can produce electricity at the cost of $51-143 € / \mathrm{MWh}$. 
Hydro. Taking into account most environmentally harmful hydro energy sources, micro and pico or "small“ hydro power plants can generate electricity at $76-94 € / M W h$, „larger" river dams, without the need of a reservoir, can generate electricity at $27-76 € / \mathrm{MWh}$.

Comparing with other studies, practice in Lithuania showed that there are limitations for larger hydropower plants due to lack of active rivers and environmental problems. Due to the geographical location, Lithuania's coastline is very slim thus making very little space for planting many wind power stations that can have a high-efficiency ratio at high wind speeds. What can be used most is applying solar technologies in residential areas to sustain residential households with electricity and fuel larger cities and industries with biopower plants, that can provide much of the electricity needed.

While using only one source of energy that costs the least would seem like the smartest move, it is not wise to depend only on one source of energy because some of these renewable energy sources do not provide a base energy needed. It is clear now that the costs of energy from RES will be greatly lower than they are now and it is only a matter of time until a full conversion to renewables happens, leaving very little fossil fuel or nuclear power plants operating.

\section{Resume}

1. Calculating levelized costs of energy is one of the possible ways to determine what the cost for energy is now of new type technologies and taking into account all assumptions, to calculate what they will be in the future, during the whole period of projects lifetime.

2. Measuring past and nowadays calculations it is clear that renewable energy is becoming cheaper and it will be in the future due to new technologies and innovations. It is a matter of which technology will advance furthest and will generate electricity at close to nothing prices.

3. Levelized cost calculations of renewable energy sources in Lithuania showed that cheapest way of generating electricity will be with bio technologies $(21-83 € / \mathrm{MWh})$, following hydro technologies (27 - $76 € / \mathrm{MWh}$ ), solar (42 - $70 € / \mathrm{MWh}$ ) and wind (58 to $152 € / M W h$ ).

\section{References}

Eurostat (2016) Energy price statistics. [online] Available at: http://ec.europa.eu/eurostat/statisticsexplained/index.php/Energy_price_statistics [Accessed 15 Dec. 2016].

FAAIJ, A. P. C. (2006) Bio-energy in Europe: changing technology choices. Energy policy 34.3, 322-342.

FERRY, R.; MONOIAN, E. (2012) A field guide to renewable energy technologies. A project of Society for Cultural Exchange \& Land Art Generator Initiative. February 2012 1st edition.

Green Rhino Energy (2016) Economics of Renewable Energy Plants. [online] Available at: http://www.greenrhinoenergy.com/renewable/context/economics.php\#CostOfEnergy [Accessed 15 Dec. 2016]. 
HANSEN, M. O. L. (2015) Aerodynamics of wind turbines. Second edition. Routledge, Earthscan. ISBN: 978-1-84407-438-9.

HERZOG, A. V.; LIPMAN, T. E. and KAMMEN, D. M. (2001) Renewable energy sources. Encyclopedia of Life Support Systems (EOLSS). Forerunner Volume-'Perspectives and Overview of Life Support Systems and Sustainable Development.

IEA, NEA (2015) Projected costs of generating electricity. International Energy Agency, Nuclear Energy Agency. Organisation for economic co-operation and development. Executive Summary. 2015 edition. [online] Available at: https://www.iea.org/Textbase/npsum/ElecCost2015SUM.pdf [Accessed 15 Dec. 2016].

IRENA (2015) Renewable Power Generation Costs in 2014. [online] Available at: https://www.irena.org/DocumentDownloads/Publications/IRENA_RE_Power_Costs_2014_report.pdf [Accessed 15 Dec. 2016].

Ivanpah solar electric generating station (2012) National renewable energy laboratory. [online] Available at: http://www.nrel.gov/csp/solarpaces/project_detail.cfm/projectlD=62 [Accessed 15 Dec. 2016].

LAZARD (2015) Levelized Cost of Energy Analysis 9.0. [online] Available at: https://www.lazard.com/media/2390/lazards-levelized-cost-of-energy-analysis-90.pdf [Accessed 15 Dec. 2016].

Levelized cost of energy (2015) U.S. Department of Energy, Office of Indian Energy. [online] Available at: http://energy.gov/sites/prod/files/2015/08/f25/LCOE.pdf [Accessed 15 Dec. 2016].

LRV (2016) Lietuvos Respublikos Vyriausybè. Atsinaujinantys energijos ištekliai. [online] Available at: https://enmin.Irv.It/lt/veiklos-sritys-3/atsinaujinantys-energijos-istekliai [Accessed 15 Dec. 2016].

REN21 (2016) Renewable Energy Policy Network for the 21st Century. Renewables 2016 Global Status Report. Paris: REN21 Secretariat. ISBN 978-3-9818107-0-7.

ROSENBERG, D. M.; MCCULLY, P.; PRINGLE, C. M. (2000) Global-scale environmental effects of hydrological alterations: introduction. BioScience 50.9, 746-751.

Torresol energy gemasolar thermosolar plant (2014) Torresol energy. [online] Available at: http://www.torresolenergy.com/TORRESOL/gemasolar-plant/en [Accessed 15 Dec. 2016].

U.S. Nuclear Regulatory Commission (2016) NRC: Glossary -- Capacity factor (net). [online] Available at: http://www.nrc.gov/reading-rm/basic-ref/glossary/capacity-factor-net.html [Accessed 15 Dec. 2016]. 